\title{
Subchronic Oral Toxicity of the Aqueous Leaf Extract of AnogeissusLeiocarpus on Albino Rats
}

\author{
*Dayom DW ${ }^{1}$, Wannang $\mathrm{NN}^{2}$, Bukar $\mathrm{BB}^{2}$, Afedia $\mathrm{E}^{3}$ \\ ${ }^{1}$ Department of Clinical Pharmacy, University of Jos. Nigeria \\ ${ }^{2}$ Department of Pharmacology, University of Jos. Nigeria \\ ${ }^{3}$ Department of ScienceLaboratory Technology, University of Jos. Nigeria
}

\begin{abstract}
Background/Purpose:- Natural products are the cornerstone of healthcare delivery in many poorresource countries like Nigeria. However, they pose great potentials for systemic toxicity which should be identified and avoided or at least minimized.

Method:- The effect of Anogeissusleiocarpus leaves was tested on the haematological parameters and some isolated organ morphology of rats following subchronic oral feeding of the rats with the aqueous extract for between 7-28 days.

Result:- The plant decreased $(p<0.05)$ platelet counts at all doses in the first 7 days of treatment. After 14-day treatment, changes in WBCs, RBCs, PCV and Hb were not significant ( $P>0.1)$. However, following 28 days of treatment, RBCs, $P C V$ and Hb increased $(p<0.05)$ while changes in other parameters were not significant. There was no significant effect on kidney, liver and heart except a decrease $(p<0.05)$ in dry weights of the isolated organs at $300 \mathrm{mg} / \mathrm{kg}$ following 28-day treatment. There was no visible histopathologicchangs in the isolated organs sectioned.

Conclusion: - Anogeissusleiocarpus leave extract caused fluctuating dose-independent changes in blood parameters and isolated organ weights. It is substantially non-toxic as the observed changes were not significant to preclude its use.
\end{abstract}

Keywords: Anogeissusleiocarpus leaf, rats, subchronic toxicity, oral feeding.

\section{Introduction}

Natural products are the cornerstone of health care delivery especially in resource poor settings. Present estimates indicate that about eighty per cent of the world's population relies on traditional medicine for healthcare delivery[1,2]. The use of plants in medicine is not limited or restricted to any region of the world. It is an age-long practice in various parts of the globe for both preventive and curative purposes. Medicinal plants have occupied a vital place in the socio-cultural development of Asia and Africa and are being modified to improve aesthetics and acceptability by users and providers alike.

Dependence on herbs for the treatment of diseases is still practised by a large proportion of the rural populace because of its ready availability and affordability[3]. These products are consists of several constituents some of which may be harmful to biological tissues. These potentials for harm should constantly be investigated and eliminated as often and as much as possible for safe use of natural products. Several studies have been conducted to test the haematological toxicity of herbal remedies[4-10]. These tests are very essential considering the fact that blood is the vehicle that transports constituents of these remedies to target sites for activity.

Anogeissusleiocarpusis a graceful tree of the Sahel to forest zones. It is used in traditional medicine as a remedy for many ailments of livestock and man, which include helminthiasis, schistosomiasis, leprosy, diarrhoea and psoriasis[11]. In the central part of Nigeria, a decoction of the leaf is widely used by traditional medical practitioners for the treatment of tuberculosis and asthma and also as antitussive. Some other herbalists use the leaf decoction for typhoid fever. Anogeissusleiocarpushave been found to possessantianaemic properties and a boost in immune system shown by increase white blood cell (WBC) count in mice confirming the ethnomedicinal use of the bark extract for malaria related anaemia[12].

Result of the intraperitoneal acute toxicity $\left(\mathrm{LD}_{50}\right)$ study of the aqueous extract has been shown to be $1400 \mathrm{mg} / \mathrm{kg}$, indicating that the extract is of low toxicity [13]. Clarke and Clarke reported that any substance with an intraperitoneal (IP) $\mathrm{LD}_{50}$ of above $1000 \mathrm{mg} / \mathrm{kg}$ should be regarded as safe [14]. A number of studies have reported the toxic effects of herbal remedies[15,16]. Several warnings have also been issued regarding potential adverse effects of herbal remedies including hepatotoxicity and nephrotoxicity[17,18].

With the upsurge of interest in medicinal plants, there is need for thorough scientific investigation of these plants for efficacy and potential toxicity. Toxicity testing is therefore very relevant to risk evaluation as changes in the histology and haematological systems in lower animals have high predictive value for human toxicity. Considering the widespread systemic use of this plant among traditional herbal practitioners in the 
middle Belt of Nigeria, this study was designed to investigate its sub-chronic effects on some isolated organs andhaematological indices in rats.

\section{Materials And Methods}

The leaves of Anogeissusleiocarpus were collected fresh from Toro Local Government Area of BauchiState along the Jos - Bauchi highway, by a herbalist, MallamLawalKabiru based in Jos along MasalachiJuma'a street. TheAnogeissusleocarpuswasidentified and authenticated by Mr. J.J Azila of Herbarinm Unit, Federal College of Forestry,Jos. Nigeria.

The leaves of the plant were air dried under shed for 5-6 days. The dried leaves was pulverised into the powdered form using pestle and mortar and the powdered material was sieved using a wire mesh. One hundred and fifty grams of powdered material of Anogeissusleiocarpus was and extracted by maceration for 24 hours in Labotec model 20.2 shaker and filtered through Whatman No. 1 filter paper using a Bauchner funnel and the extract was concentrated to dryness.

\subsection{Experimental Design}

Eighty healthy adult Wistar albino rats of both sexes weighing between $100-170 \mathrm{~g}$ were used for the study. They were maintained and observed on a daily basis for seven days in the animal house unit of the University of Jos and were fed with standard diet and had free access to fresh clean water.

The animals were divided into four groups of 20 rats each.Group 1 ratswere given distilled water daily orally as the control group. Groups 2 - 4(treatment groups) were allowed free access to $16.7 \mathrm{mg} / \mathrm{ml}, 33.3 \mathrm{mg} / \mathrm{ml}$ and $50.0 \mathrm{mg} / \mathrm{mlaqueous}$ solutions of the extract respectively as their only source of drinking water throughout the experiment until picked for sample collection. Five rats were randomly pickedfrom each group (totalling 20) on days $7,14,21$ and 28 for the study.

\section{2,2Collection of Blood Samples and Isolated Organs}

Each of the animals picked was anesthetized with $10 \%$ chloroform soaked in cotton wool and placed in a desiccator. The heart was exposed and blood sample was collected by cardiac puncture. A needle and a syringe was used to puncture the apex of the heart and as much blood as possible was collected and transferred immediately to an EDTA bottle. This was mixed gently and thoroughly, this process was repeated for every rat.The packed cell volume (PCV), red blood cell (RBC) count, white blood cell (WBC) count, platelets count and haemoglobin $(\mathrm{Hb})$ estimation were carried out. Red blood cells and WBCs were estimated by means of a haemocytometer and Microscope, PCV was estimated using a haematocrit reader, and haemoglobin concentration was estimated with a colorimeter and platelets. The heart, liver and kidneys of rats picked on days 7 and 28 in each group were isolated and their dry weights measured.The isolated organs were fixed in $10 \%$ formalin and later sectioned for histopathologicalexaminationas described [19]. Slides were observed using X400 objective from where photographs were recorded. In all measurements, the treated groups were compared with the control.

\subsection{Statistical Analysis}

The results obtained were expressed as mean \pm sem and the differences were compared using one way ANOVA and considered significant at $(P<0.05)$.

\section{Results}

3.1 Effects of graded doses of extract on haematological indices:After 7 days of treatment with extract, the RBCs decreased

from $107.04 \pm 5.85$ (in the control) to $83.40 \pm 7.36(\mathrm{p}<0.05)$ and $67.16 \pm 5.58(\mathrm{p}<0.001)$ at doses of $33.3 \mathrm{mg} / \mathrm{ml}$ and $50.0 \mathrm{mg} / \mathrm{ml}$ respectively. Platelet counts decreased significantly at all doses of extract while haemoglobin concentration increased significantly $(\mathrm{p}<0.001)$ at the dose of $16.7 \mathrm{mg} / \mathrm{ml}$. the changes in WBC counts and PCV were not statistically significant (TABLE 1 ).

At the end of 14days of treatment, platelet levels decreased significantly $(\mathrm{p}<0.05)$ at dose of $33.3 \mathrm{mg} / \mathrm{ml}$ of extract. Changes in RBCs, WBCs, haemoglobin concentration and PCV values were not significant $(\mathrm{P}>0.1)$ at all doses of the extract (TABLE 2). By the $21^{\text {st }}$ day of treatment, RBCs reduced significantly $(\mathrm{p}<0.05)$ at all doses of extract tested. WBCs and platelet counts also decreased significantly $(p<0.001)$ at all doses of extract while changes in $\mathrm{Hb}$ and PCV were not significant (TABLE 3).

In the $4^{\text {th }}$ week of treatment, RBC count increased significantly $(\mathrm{p}<0.001)$ from $76.52 \pm 6.78 \times 10^{3}$ (in the control) to $122.40 \pm 7.07 \times 10^{3}(\mathrm{p}<0.05)$ and $123.88 \pm 4.59 \times 10^{3}(\mathrm{p}<0.001)$ at doses of $33.3 \mathrm{mg} / \mathrm{ml}$ and $50.0 \mathrm{mg} / \mathrm{ml}$ respectively. $\mathrm{Hb}$ and $\mathrm{PCV}$ also increased significantly $(\mathrm{p}<0.05)$ at $16.7 \mathrm{mg} / \mathrm{ml}$ and $33.3 \mathrm{mg} / \mathrm{ml}$ of extract in the fourth week of treatment with extract. Changes in WBCsand platelet counts were not statistically significant (TABLE 4). Changes in blood parameters were not generally time dependent for most blood indices measured. 
3.2 Effect of dose and duration of treatment on dry weights and histology of the liver, heart and kidneys:Changes in thedryweights of isolated organs did not follow a defined pattern. These changes were not significant $(p>0.1)$. However, at 28 days, treated groups showed decrease in liver, heart and kidney dry weights dose-dependently when compared with the control. These decreases were significant $(p<0.05)$ at the highest dose of $50.0 \mathrm{mg} / \mathrm{ml}$ tested. Empirical observation also showed weights of rats in the 28-day treatment were higher than those of 7-day treatment (TABLE 5). There was no visible histopathologicaldefect observed in the isolated organs of the rats treated with the extract compared to the control (fig. 1 - 3).

\section{Dicussion}

The continuous evaluation of medicinal plant products as potential therapeutic agents is encouraged by the isolation of phytochemicals in plants which could become important drugs in modern medicine[20]. Complete blood evaluation provides enormous information on the haematological status in disease conditions. Anaemia is usually assessed by evaluating the packed cell volume (PCV), haemoglobin concentration $(\mathrm{Hb})$ and red blood cells (RBC) counts where low levels are predictors for anaemia. The blood, liver, kidney and the skin are the most vulnerable sites of first manifestations toxic effects of drugs.

In this study,there was no definite pattern of changes in the haematological profiles of the rats with dose and time variations of extract of Anogeissusleiocarpus. However, the extract was generally shown to significantly decrease RBCs dose-dependently in the first week of treatment with the extract while there was significant increase in RBCs in the third and fourth weeks.RBCs are very important in the transport of oxygen from the lungs to the tissues and haemoglobin concentration s directly correlated with the RBC counts. This is due to thesynergistic links among these blood parameters in all vertebrates [21].

The mechanism leading to the increase RBC counts in the second and third weeks is probably mediated by constituents in Anogeissusleiocarpus with antioxidant properties. Previous study has shown that prohylactive and therapeutic oral administration of antioxidant supplements (vitamins $\mathrm{C}$ and $\mathrm{E}$ )significantly increased cells of haemopoeitic origin in animals [22]. It may also have resulted from the extracellular influence on the stimulant cytokine erythropoietin[23]. White blood cell (WBC) counts and haemoglobin concentration generally increased dose-dependently in the first and fourth weeks but decreased dose-dependently in the second and third weeks of treatment with the extract. The increased WBC counts may be due to activation of the animal's defence mechanisms and the immune systems by toxic chemicals in the extract. Red blood cells, WBCs and platelets are made in the bone marrow and their characteristics are widely used in the diagnosis of a variety of diseases and pathologies induced by drugs, heavy metals, industrial compounds, pesticides etc[24]. Tuberculosis for which this plant is used traditionally is a chronic disease that requires long term drug administration, the benefit of any drug material for such chronic administration to achieve the desired therapeutic outcome must be so demonstrated against any risk of toxicity.

The extract significantly $(\mathrm{p}<0.001)$ decreased platelet count at all doses in the first and third weeks but insignificantly $(\mathrm{p}>0.1)$ in other weeks of treatment. This may be due to toxic potentials of Anogeissusleiocarpuson platelet-producing cells and this has great implications on clotting factors and blood clotting. Generally, the extract increased PCV in the rats. These increases were only significant $(p<0.05)$ at $16.7 \mathrm{mg} / \mathrm{ml}$ and $33.3 \mathrm{mg} / \mathrm{ml}$ doses in the fourth week of treatment. The PCV (haematocrit) is the proportion of blood volume that is occupied by RBCs. An increase in haematocrit value can be attributable to total cell increase in peripheral blood aided by extract's disturbance in steady state mechanisms in blood forming organs as well as decrease in plasma volume.

The insignificant changes in the dry weights of isolated organs in the first seven days of treatment at all doses in this experiment are a measure of safety of the plant. However, the $300 \mathrm{mg} / \mathrm{kg}$ dose which significantly reduced the isolated organ weights after 28 days of chronic ingestion of the drug is far in excess of the usual local dose of this. The survival of the animals for 28 days on daily administration of $50.0 \mathrm{mg} / \mathrm{ml}$ dose of the extract is indicative of the safety of the plant for chronic use and thus substantiating and supporting its safety for treatment of chronic ailments like asthma and tuberculosis. Orally administered drugs and compounds do undergo some events that potentially decrease the amount reaching systemic circulation for pharmacological effects[25].

\section{Conclusion}

The aqueous extract of Anogeissusleiocarpusleaves caused fluctuating levels of RBC, WBC, PCV and $\mathrm{Hb}$ levels in rats dose-independently. It consistently reduced platelet levels at all doses tested. The plant extract significantly reduced the dry weights of isolated organs after 28 -day treatment at $300 \mathrm{mg} / \mathrm{kg}$ of the extract. There was no histopathological changes in the isolated organs. Anogeissusleiocarpus leaf is therefore safe for the intended use in traditional medicine. 


\section{References}

[1] P.A.Akah, Indigenous Knowledge and Medical Practice, In P.A. Akah (Ed.), Ethnopharmacology(Research Signpost, Kerela, India. 2008, 1-13).

[2] J.R. Appidi, D.S. Grierson, and A.S. Afolayan,Ethnobotanical study of plants used for the treatment of diarrhoea in the Eastern Cape South Africa. Pakistan J. Biol. Sc. 11,2008, 1961-1963.

[3] D. Sani, S. Sanni, and S.I. Ngulde, Phytochemical and antimicrobial screening of aqueous extract of the stem of Anisopusmannii. J. Med Plant Res., 3,2009, 112-115.

[4] S.S. Baghel, S. Dangi,SoniP, P. Singh and Y. Shivhare,Acute Toxicity Study of Aqueous Extract of Cocciniaindica(Roots) Asian J. Res. Pharm.; Vol. 1(1),2011, 23-25.

[5] C.E. Ekpenyong, U.P. Akpan, E.E. Ben, E.O. Nwama and J.O. Ibu, Haematological effect of chronic administration of ethanolic extract ofGarciniaconruanaseed on rat,Journal of Natural Products, Vol. 4,2011, 173-176.

[6] A. Singh, R. Kumar, Nivedita, J.K. Singh andTanuja,Radioprotective effect of Eclipta alba (L.) against radiation induced haematological changes in Swiss albino mice.Journal of Natural Products, Vol. 4, 2011, 177-183.

[7] E.E. Ilodigwe, P.A. Akah, C.S. Nworu, Evaluation of the Acute and Subchronic Toxicities of Ethanol Leaf Extract of SpathodeacampanulataP.Beauv. International Journal of Applied Research in Natural Products Vol. 3 (2), $2010,17-21$.

[8] A. Lagarto, V. Bueno, I. Guerra, O. Valdés, T. Gabilondo and J. Rodríguez, Acute and Subchronic Oral Toxicities of Justiciapectoralisextract in WistarRats, The Open NaturalProducts Journal, 2, 2009,53-58.

[9] S.A. Mansour1, A.H. MossaandT.M. Heikal,Haematoxicity of a New Natural Insecticide "Spinosad" on Male Albino Rats. International Journal of Agriculture \& Biology. 2, 2007, 342-346.

[10] A.O.T. Ashafa, T.O. Sunmonu and A.J. Afolayan,Effects of leaf and berry extracts of PhytolaccadioicaL. on haematological and weight parameters of Wistarrats, African Journal of Pharmacy and Pharmacology Vol. 5(2), 2011, 150-154.

[11] P.A. Onyeyili, Anthelminthic efficacy of some plants used in ethnoveterinary practices in the Arid zone of North Eastern Nigeria. RGA No. 28 project Report, 2000.

[12] M.C. Cyril-Olutayo, A.A. Omonkhua1 andO.M. Akanbi,Effects of Anogeissusleiocarpuson Haematological Parameters ofMice Infected with Plasmodium berghei.Journal of Plant Studies; Vol. 2, (2), 2013, 13- 21.

[13] B.M. Agaie, P.A. Onyeyili, B.Y. Muhammad and M.J. Ladan, Acute toxicity effects of the aqueous leaf extract of Anogeissusleiocarpusin rats; African Journal of Biotechnology, Vol. 6, (7), 2007, 886-889.

[14] E.G. Clarke and M.L. Clarke, Vet. Toxicol. $3^{\text {rd }}$ ed. (Bailliere Tindal, New York. 1975).

[15] E.H. Jaouad, Z.H. IsrailliandB..Lyoussi, Acute toxicity and chronic toxicological studies of Ajugaivain experimental animals,JEthnopharmacol. 91, 2004, 43-50.

[16] L.C. Taziebou, F.X. Etoa, B. Nkegoum, C.A. PiemeandD.P.D. Dzeufiet, Acute and subacute toxicity of Aspiliaafricanaleaves.Afr. J. Trad. CAM 4(2), 2008, 127-134.

[17] F. Stickel, E. PatsenkerandD. Schuppan, Herbal hepatotoxicity.J Hepatol., 43, 2005, 901-910.

[18] L.B. Seeff, Herbal hepatotoxicity,Clinics Liver Dis., 11, 2007, 577-596.

[19] R.A.B. Drury and E.A. Wallington, Carteton Histological Techniques. $4^{\text {th }}$ ed. (Oxford University Press, London. 1976, 21-70).

[20] O.A. Wintola, T.O. SunmonuandA.J. Afolayan, The effect of Aloe ferox Mill.in the treatment of loperamide-induced constipation in Wistar rats.BMC Gastroenterol,2010,10:95.

[21] A.S. El-Bakary, A.F. Abdel-Gawad, M.M. El-Moftyand S.I. Attia,Effect of dimethoate on some haematological parameters of ToadBuforegularis. J King Saud University, 7, 1995, 85-93.

[22] C. Wambi, J.S.S. Wani, M. NuthandJ. Davis,Dietary Anti-oxidant Protect Hematopoietic Cells and Improve Animal Survival after Total-Body Irradiation. Radial Res., 169 (4), 2008, 384-396.

[23] A.A. AhumibeandV.B.Braide, Effect of gavage treatment with pulverized garcinia kola seeds on erythrocyte membrane integrity and selected haematological indices inmale albino wistar rats. Nig. J. Physiological Sc., 24 (1), 2009, 47-52.

[24] S.A. Mansour and A.H. Mossa, Comparative effects of some insecticides as technical and formulated on male albino rats. J. EgyptSoc. Toxicol., 32, 2005, 41-54.

[25] G.C. Brander, D.M. Pugh, R.J. Bywater, W.L. Jerkins, Veterinary Applied Pharmacology, Ther. $5^{\text {th }}$ ed. (Bailliere Tindal, London. 1991, 513-547).

Table 1: Effect of graded doses of extract on haematological indices in rats after 7 days of treatment

\begin{tabular}{|c|c|c|c|c|c|}
\hline Treatment & $\begin{array}{c}\mathrm{RBC} \\
\left(\mathrm{X} 10^{5} / \mathrm{mm}^{3}\right) \\
\end{array}$ & $\begin{array}{l}\text { WBC } \\
\left(\mathrm{X} 10^{3} / \mathrm{mm}^{3}\right)\end{array}$ & $\begin{array}{l}\text { PLATELETS } \\
\left(\mathrm{X} 10^{5} / \mathrm{mm}^{3}\right) \\
\end{array}$ & $\begin{array}{l}\mathrm{PCV} \\
(\%) \\
\end{array}$ & $(\mathrm{g} / \mathrm{dl})$ \\
\hline Distilled water & $107.04 \pm 5.85$ & $31.65 \pm 4.59$ & $4.0 \pm 0.14$ & $30.6 \pm 2.4$ & $38.2 \pm 1.02$ \\
\hline Extract $(16.7 \mathrm{mg} / \mathrm{ml})$ & $108.4 \pm 11.44$ & $39.6 \pm 5.21$ & $2.44 \pm 0.19^{* *}$ & $33.0 \pm 0.9$ & $47.4 \pm 1.12 * *$ \\
\hline Extract $(33.3 \mathrm{mg} / \mathrm{ml})$ & $83.40 \pm 7.36^{*}$ & $34.0 \pm 3.06$ & $2.64 \pm 0.42 *$ & $28.4 \pm 1.2$ & $40.4 \pm 3.68$ \\
\hline Extract $(50.0 \mathrm{mg} / \mathrm{ml})$ & $67.16 \pm 5.58 * *$ & $40.15 \pm 6.26$ & $1.84 \pm 0.41^{* *}$ & $27.0 \pm 1.4$ & 32.24 .79 \\
\hline
\end{tabular}


$* * p<0.001$

Table 2: Effect of graded doses of extract on haematological indices after 14 days of treatment

\begin{tabular}{llllll}
\hline Treatment & $\begin{array}{l}\mathrm{RBC} \\
\left(\mathrm{X} 10^{5} / \mathrm{mm}^{3}\right)\end{array}$ & $\begin{array}{l}\mathrm{WBC} \\
\left(\mathrm{X} 10^{3} / \mathrm{mm}^{3}\right)\end{array}$ & $\begin{array}{l}\text { PLATELETS } \\
\left(\mathrm{X} 10^{5} / \mathrm{mm}^{3}\right)\end{array}$ & $\begin{array}{l}\text { PCV } \\
(\%)\end{array}$ & $\begin{array}{l}\text { HB } \\
(\mathrm{g} / \mathrm{dl})\end{array}$ \\
\hline Distilled water & $87.64 \pm 4.36$ & $34.4 \pm 12.07$ & $2.26 \pm 0.30$ & $23.4 \pm 2.11$ & $45.8 \pm 3.76$ \\
Extract $(16.7 \mathrm{mg} / \mathrm{ml})$ & $95.90 \pm 5.77$ & $33.6 \pm 3.19$ & $1.64 \pm 0.13$ & $25.6 \pm 0.87$ & $40.6 \pm 1.17$ \\
Extract $(33.3 \mathrm{mg} / \mathrm{ml})$ & $86.88 \pm 4.58$ & $29.7 \pm 5.90$ & $0.96 \pm 0.26^{*}$ & $27.4 \pm 1.69$ & $35.2 \pm 3.09$ \\
Extract $(50.0 \mathrm{mg} / \mathrm{ml})$ & $93.12 \pm 5.86$ & $31.85 \pm 5.98$ & $1.48 \pm 0.44$ & $28.6 \pm 0.87$ & $37.4 \pm 2.25$ \\
\hline $\mathrm{n}=5$ & & & & &
\end{tabular}

${ }^{*} p<0.05$

Table 3: Effect of graded doses of extract on haematological indices after 21 days of treatment

\begin{tabular}{|c|c|c|c|c|c|}
\hline Treatment & $\begin{array}{l}\text { RBC } \\
\left(\mathrm{X} 10^{5} / \mathrm{mm}^{3}\right)\end{array}$ & $\begin{array}{l}\text { WBC } \\
\left(\mathrm{X} 10^{3} / \mathrm{mm}^{3}\right)\end{array}$ & $\begin{array}{l}\text { PLATELETS } \\
\left(\mathrm{X} 10^{5} / \mathrm{mm}^{3}\right) \\
\end{array}$ & $\begin{array}{l}\text { PCV } \\
(\%) \\
\end{array}$ & $\begin{array}{l}\mathrm{HB} \\
(\mathrm{g} / \mathrm{dl}) \\
\end{array}$ \\
\hline Distilled water & $117.16 \pm 6.41$ & $6 i .76 \pm 3.13$ & $3.64 \pm 0.18$ & $30.8 \pm 0.37$ & $42.8 \pm 3.17$ \\
\hline Extract $(16.7 \mathrm{mg} / \mathrm{ml})$ & $88.72 \pm 6.88^{*}$ & $15.57 \pm 5.25^{* *}$ & $0.44 \pm 0.15^{* *}$ & $30.2 \pm 0.37$ & $41.2 \pm 3.83$ \\
\hline Extract $(33.3 \mathrm{mg} / \mathrm{ml})$ & $97.96 \pm 5.85^{*}$ & $20.7 \pm 6.70 * *$ & $0.88 \pm 0.35^{* *}$ & $30.2 \pm 0.37$ & $45.60 \pm 3.7$ \\
\hline Extract $(50.0 \mathrm{mg} / \mathrm{ml})$ & $89.07 \pm 8.07^{*}$ & $15.0 \pm 4.47 * *$ & $0.4 \pm 0.13 * *$ & $28.6 \pm 1.96$ & $39.8 \pm 4.75$ \\
\hline $\begin{array}{l}\mathrm{n}=5 \\
* p<0.05 \\
* * p<0001\end{array}$ & & & & & \\
\hline
\end{tabular}

Table 4: Effect of graded doses of extract on haematological indices after 28 days of treatment

\begin{tabular}{|c|c|c|c|c|c|}
\hline Treatment & $\begin{array}{l}\text { RBC } \\
\left(\mathrm{X} 10^{5} / \mathrm{mm}^{3}\right)\end{array}$ & $\begin{array}{l}\text { WBC } \\
\left(\mathrm{X} 10^{3} / \mathrm{mm}^{3}\right)\end{array}$ & $\begin{array}{l}\text { PLATELETS } \\
\left(\mathrm{X} 10^{5} / \mathrm{mm}^{3}\right) \\
\end{array}$ & $\begin{array}{l}\text { PCV } \\
(\%) \\
\end{array}$ & $\begin{array}{l}\text { HB } \\
(\mathrm{g} / \mathrm{dl})\end{array}$ \\
\hline Distilled water & $76.52 \pm 6.78$ & $19.7 \pm 2.75$ & $0.76 \pm 0.04$ & $24.0 \pm 2.59$ & $33.2 \pm 3.29$ \\
\hline Extract $(16.7 \mathrm{mg} / \mathrm{ml})$ & $122.4 \pm 7.07 *$ & $18.3 \pm 0.97$ & $1.32 \pm 0.43$ & $31.8 \pm 0.86^{*}$ & $49.2 \pm 1.59^{*}$ \\
\hline Extract $(33.3 \mathrm{mg} / \mathrm{ml})$ & $123.88 \pm 4.59 * *$ & $24.19 \pm 6.15$ & $0.76 \pm 0.1$ & $31.0 \pm 0.55^{*}$ & $46.0 \pm 2.45^{*}$ \\
\hline Extract $(50.0 \mathrm{mg} / \mathrm{ml})$ & $77.10 \pm 3.94$ & $27.82 \pm 4.75$ & $1.06 \pm 0.23$ & $31.6 \pm 0.81$ & $31.6 \pm 0.81$ \\
\hline $\begin{array}{l}\mathrm{n}=5 \\
*_{p}<0.05 \\
* *_{p}<0.001\end{array}$ & & & & & \\
\hline
\end{tabular}


Table 5: Effect of dose and duration of treatment on dry weight of isolated organs

\begin{tabular}{|c|c|c|c|c|}
\hline \multirow[t]{2}{*}{ Treatment } & Rat weight (g) & Liver weight (g) & Heart weight (g) & Kidney weight (g) \\
\hline & Mean \pm sem & Mean \pm sem & Mean \pm sem & Mean \pm sem \\
\hline \multicolumn{5}{|l|}{ Week 1} \\
\hline $\begin{array}{l}\text { Distilled water } \\
\text { Extract }\end{array}$ & $128.75 \pm 6.52$ & $1.08 \pm 0.06$ & $0.13 \pm 0.01$ & $0.16 \pm 0.01$ \\
\hline $\begin{array}{l}(16.7 \mathrm{mg} / \mathrm{ml}) \\
\text { Extract }\end{array}$ & $131.25 \pm 5.15$ & $1.27 \pm 0.10$ & $0.17 \pm 0.03$ & $0.19 \pm 0.04$ \\
\hline $\begin{array}{l}(33.3 \mathrm{mg} / \mathrm{ml}) \\
\text { Extract }\end{array}$ & $122.50 \pm 11.09$ & $1.27 \pm 0.21$ & $0.11 \pm 0.01$ & $0.12 \pm 0.01$ \\
\hline$(50.0 \mathrm{mg} / \mathrm{ml})$ & $113.75 \pm 6.90$ & $0.92 \pm 0.21$ & $0.15 \pm 0.01$ & $0.22 \pm 0.10$ \\
\hline \multicolumn{5}{|l|}{ Week 4} \\
\hline $\begin{array}{l}\text { Distilled water } \\
\text { Extract }\end{array}$ & $142.75 \pm 10.84$ & $1.53 \pm 0.14$ & $0.13 \pm 0.00$ & $0.13 \pm 0.00$ \\
\hline $\begin{array}{l}(16.7 \mathrm{mg} / \mathrm{ml}) \\
\text { Extract }\end{array}$ & $146.30 \pm 8.50$ & $1.30 \pm 0.05$ & $0.13 \pm 0.00$ & $0.12 \pm 0.00$ \\
\hline $\begin{array}{l}(33.3 \mathrm{mg} / \mathrm{ml}) \\
\text { Extract }\end{array}$ & $155.00 \pm 10.41$ & $1.31 \pm 0.04$ & $0.13 \pm 0.01$ & $0.12 \pm 0.00$ \\
\hline$(50.0 \mathrm{mg} / \mathrm{ml})$ & $127.50 \pm 7.50$ & $1.15 \pm 0.04^{*}$ & $0.11 \pm 0.00^{*}$ & $0.11 \pm 0.00^{*}$ \\
\hline
\end{tabular}

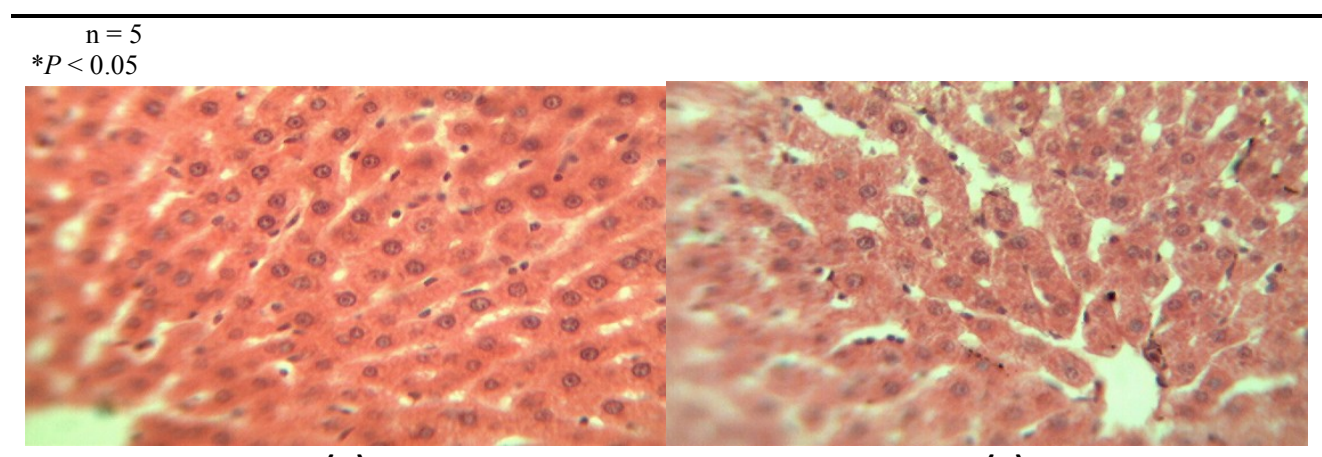

(A)

(B)

Figure 1 Section of the liver (x400), (A) treated with distilled water for 7days and(B) treated with $50.0 \mathrm{mg} / \mathrm{ml}$ ofextractfor $28 d a y s$

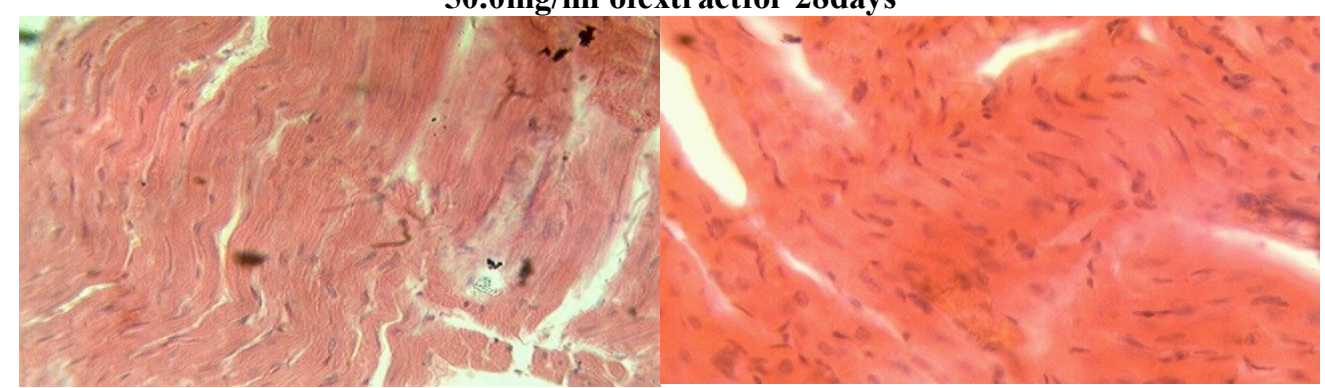

(A)

(B)

Figure 2 Section of the heart (x400), (A) treated withdistilled water for 7 days and (B) treated with $50.0 \mathrm{mg} / \mathrm{ml}$ of theextract for $28 d a y s$

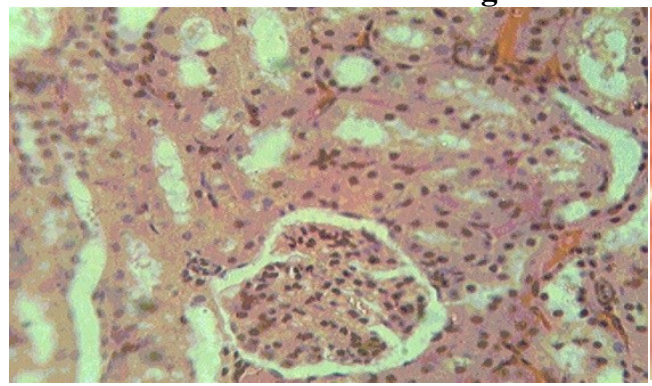

(A)

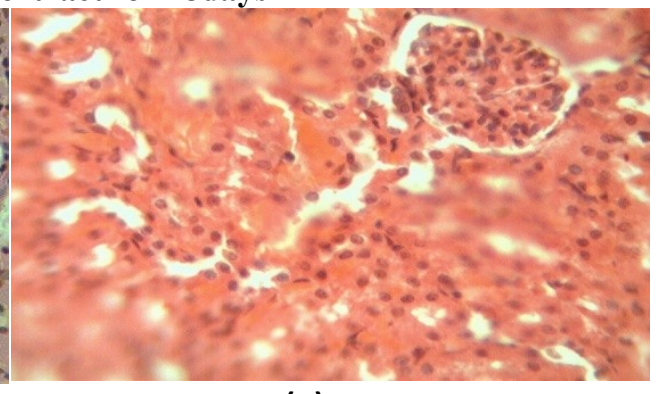

(B)

Figure 3 Section of the kidney (x400), (A)treated with distilled water for 7 days and $(B)$ treated with $50.0 \mathrm{mg} / \mathrm{ml}$ ofextract for $28 \mathrm{days}$ 